\title{
Effectiveness of Casein Phosphopeptide-Amorphous Calcium Phosphate on the Prevention of White Spot Lesions: A Systematic Review and Meta-Analysis
}

\author{
Defne Kecik1, ${ }^{*}$ \\ ${ }^{1}$ Associate Professor, Department of Orthodontics, Faculty of Dentistry, Istanbul Hospital, Baskent University, Istanbul, Turkey \\ "Corresponding author: Defne Kecik, Associate Professor, Department of Orthodontics, Faculty of Dentistry, Istanbul Hospital, Baskent University, Istanbul, Turkey. Tel: \\ +90-5325643989, E-mail: defnekecik@gmail.com
}

Received 2016 May 20; Accepted 2016 September 18.

\begin{abstract}
Context: One of the most important aspects of dental profession is to consider the effectiveness of the preventive systems applied and maintain the good oral hygiene, oral health and minimize the risk of caries among the patients. A great spectrum of preventive activities and materials like fluoride applications, fissure sealants; also new technologies like Casein Phosphopeptide-Amorphous calcium phosphate (CCP-ACP) have a wide effect on preventing caries.

Objective: The objective of this systematic review with meta-analysis was to review systematically the clinical trials of CPP-ACP complex and determine the caries preventive effects on the remineralization process.

Data Sources: PubMed, Google Scholar, biomed central, cochrane oral health reviews, Cochrane library, directory of open access journals, Ovid Medline, Web of science and EMBASE were searched up to February 2016. Only articles in English were included. Trials that were considered clinically and methodologically homogeneous and reported on similar outcomes were pooled for metaanalyses. The clinical studies that inspected the effects of casein derivatives in dental practice were included. In vitro studies, case reports, case series, letters to the editors, editorials, review articles and commentaries were not included for the statistical analysis but evaluated to identify the potential outcomes of the further studies.

Study Selection: Of the 3859 studies screened 92 studies were assessed for eligibility, and 22 were selected for inclusion and 11 was in the final sample for meta-analysis. Systematic review was assessed and the remineralization effect of CPP-ACP was demonstrated compared to placebo in the meta-analysis.

Conclusions: The evaluated systematic review with meta-analyses, clinical trials showed the remineralization effect of CPP-ACP on early caries lesions mainly the white spot lesions (WSL's). In vivo RCT studies reveal a promising caries preventing effect, inducing remineralization and treating dentin hypersensitivity and dry mouth with the use of clinical CPP-ACP application.
\end{abstract}

Keywords: Remineralization, Decalcification, Caseine Phosphopeptide-Amorphous Calcium Phosphate, Meta-Analysis, White Spot Lesions

\section{Context}

Dental caries is a major public health problem among the whole world. It is becoming a controlled problem with fluoride enriched water and personal hygiene applications; however cariogenicity threatens the healthcare system to a greater extent compared to heart diseases, cancer, diabetes or hypertension $(1,2)$.

Caries lesions are the clinical manifestation of pathogenic process that may have been occurring on the dental surface over months or years. The first step of cariogenicity is that oral bacteria start to decay the food interacting with mucopolysaccarides like sucrose on the enamel surface. Dental plaque bacteria metabolize dietary sugars to produce organic acids that solubilize tooth enamel's hydroxyapatite crystals. During the exposure of the enamel to organic acids, solid calcium phosphate is solubilized to free calcium. This process is called demineralization and it is reversible to some point by the presence of salivary sodium bicarbonate aiding remineralization (3).

High risk of dental caries is dependent on the variables such as ethnicity and low socioeconomic status. These threatening epidemiologic variations had led the researchers and product developers search for products to reduce the prevalence of dental caries. Mainly the products that are convenient and easy to use for the customer such as chewing gums and sugar-free products that protects the tooth decay at a degree. Dental caries is still the predominant cause of tooth loss. One of the most effective approaches used to protect the populations from cavities have been leading them to consume dairy products and mostly milk, as they have been identified as one of the most important cariostatic factors (3). 
Milk is an excellent protein providing essential amino acids and organic nitrogen and containing anticariogenic properties like calcium, phosphate, lipids and caseine for humans of all ages. Dairy products were started to consume as a food group that is effective in preventing dental caries in the late 1950s (4). Researches have focused on isolating protective factors from milk to use as food additives or specific agents to reduce cariogenicity.

Casein is the most important phosphoprotein in bovine milk with a $80 \%$ of the concentration (5). Several studies have evaluated the low cariogenity and the cariostatic activity of the dairy products such as milk, casein and cheese (5-10). Casein phosphopeptides (CPP) can stabilize calcium phosphate in state-forming CPP- amorphous calcium phosphate (ACP) complex $(11,12)$. The CPPACP complex was patented by the University of Melbourne, Australia and the Victorian diary industry authority, Abbotsford, Australia and the trademark is Recaldent, owned by Bonlac foods limited. The commercial names of CPPACP are labeled as MI Paste and MI paste plus or GC tooth mousse or tooth mousse plus varying according to the marketing region. It is used primarily as abrasive prophylaxis paste and secondarily for the treatment of tooth sensitivity. The use of the CPP-ACP for remineralization of the enamel and dentin and the prevention of dental caries is the other major application alternative. Since CPP has a more anticariogenic activity compared to casein, it can be used as an anticariogenic additive to food and toothpaste (12). According to Reynolds et al. (11, 13) CCP-ACP binds readily to tooth surface and to the bacterial plaque around the tooth. Thus, CCP-ACP deposits a highly concentrated ACP around the tooth surface and the localized CPP-ACP buffers the free calcium and phosphate ions increasing the level of calcium phosphate in plaque; therefore maintain a state of supersaturation inhibiting enamel demineralization and enhancing remineralization. Rose (14) stated that CPP-ACP binds well to dental plaque providing a large calcium reservoir inhibiting the demineralization and providing remineralization. It is also demonstrated that enamel remineralized by CPP-ACP is relatively more acid-resistant than normal tooth enamel $(15,16)$.

Roberts (17) have stated that treatment of enamel swabs in vitro with CPP inhibits acid preparation via stimulating the reminaralization by calcium uptake into enamel (18). This mechanism could control acid formation in dental plaque and reducing hydroxyapatite dissolution from tooth enamel (19).

CPP also has the capability to bind the cell walls of the potential dental pathogens such as Streptococcus sobrinus and Streptococcus sangius resulting in another possible mechanism for anticariogenicity.

\section{Objective}

The purpose of this meta-analysis is to evaluate the clinical efficacy of CPP-ACP and systematically review the clinical usage and benefits of CPP-ACP when introduced to oral environment; this meta-analysis aimed to answer the question: Does topical CPP-ACP application induce remineralization of the enamel and enhance the white spot lesions.

\section{Data Sources}

\subsection{Search Criteria}

The literature search involved the electronic databases: PubMed, Google Scholar, Biomed central, Cochrane oral health reviews, Cochrane library, directory of open access Journals, Ovid Medline, Web of science and EMBASE. The search terms were identified as MI Paste, Recaldent, Caseine phosphopeptide-amorphous calcium phosphate, CPP-ACP, Tooth Mousse.

\subsection{Inclusion and Exclusion Criteria}

Randomized controlled clinical trials or controlled clinical trials using topical CCP-ACP in any form such as toothpaste, mouth rinses, tooth mousse and chewing gum were included. Case reports, editorials, case series, in vitro studies were excluded.

\subsection{Participants}

Humans with white spot lesions on enamel surface was included.

\subsection{Outcomes}

The main outcome measure was the decrease in white spot lesions and caries prevention indicated by improvement in DMFT/DMFS/DFS scores or a remineralization percentage. A change in the number of white spot lesion was one of the outcomes.

\subsection{Intervention and Control}

Only studies that compared the following strategies were included:

- Noninvasive treatment: remineralization with the agents containing CPP-ACP such as chewing gums, tooth pastes, tooth mousse, topical creams.

- Control: no active treatment or placebo application. 


\subsection{Data Extraction and Quality Assessment}

Of the screened 3859 articles, 92 were reviewed and resulted in 22; which is eligible for systematic review (15, 16, 20-30, 31-39); finally 11 were eligible for meta-analysis $(20,23-28)$. The primary outcome of these studies was the reduction in caries increment (an improvement in DMTF/DMFS/DFS scores) and the change in proportion of the white spot lesions (remineralization percentage) (31, 33-37). The following data was collected: authors and publication year, number and age of participants, intervention and control details, check-time points, method of assessment, reported outcomes. Each study was evaluated by the method described in Cochrane handbook of systematic reviews of interventions 5.1.0; which is the official guideline describing in detail the process of preparing and maintaining Cochrane systematic reviews on the effects of healthcare interventions. The evaluation was done in random sequence generation, blinding, allocation concealment and selective outcome reporting.

\subsection{Risk of Bias Assessment}

Selection bias (allocation concealment, sequence generation) performance and detection bias (blinding of participants, examiners), attrition bias (follow-up loss or missing values of participants) and reporting bias (selective reporting, missing outcomes) were evaluated according to Cochrane's guidelines (40).

\section{Results}

\subsection{Results of the Search}

Throughout the electronic databases 3859 were related with this subject. Following the elimination of the case reports, case series, editorials, letters to the editor and in vitro studies, 92 eligible studies were evaluated full-text. 22 of them were included in the systematic review and 11 RCT in situ studies with homogenous data allocation were selected for meta-analysis.

The treatment procedures and the style of study design for all the evaluated articles included in the systematic review were shown in Table 1.

\subsection{Pooling Data for Meta-Analysis}

Clinically and methodologically homogenous data were pooled for meta-analysis.

The caries preventive effect of the applied agents with and without CPP-ACP reveals that the weighed mean difference had a significant value in favor of CCP-ACP group.

Figure 1 provides information on the overall weight of evidence for the remineralization and caries-preventive effect of CPP-ACP. All studies had a crossover in situ design with similar intervention style. 8 studies $(20,23-25,28,31$, $33,35)$ showed a significant remineralization effect $(\mathrm{P}<$ 0.01 and $\mathrm{P}<0.001)$ whereas 3 studies $(34,36,37)$ showed no difference of remineralization between groups $(\mathrm{P}>0.05)$.

The mean differences were calculated to reflect the size of the treatment effect between the intervention and control groups.

The cumulative weight of evidence for the cariespreventive effect of CPP-ACP (delivered via sugar-free gum) when compared to that of sugar-free gum without CPPACP showed an increase. The data sets, from 8 trials (Figure 1) with individual weighted mean differences (WMDs) for control and intervention groups showed an increase, whereas 3 studies did not show a meaningful remineralization.

The results showed a significant regression in white spot lesions with the use of clinical inspection of the lesions via visual scoring on a scale, ICDAS Criteria, DMFS index, Laser fluorescence reading (DIAGNOdent), or QLF assessment.

\section{Discussion}

The aim of this systematic review with meta-analysis was to identify the caries preventive effect of CPP-ACP via the published randomized clinical trials and clinically controlled trials. All the studies used in this meta-analysis were in situ randomized controlled trials with a crossover component.

Concerning the white spot and caries lesions exposed to CPP-ACP were inspected to have a significant improvement in remineralization compared to control group lack of CPP-ACP. The results obtained from this meta-analysis suggest that a long-term exposure to CPP-ACP is favorable for an even greater treatment effect in terms of the caries preventive activity. The study design with percentage outcomes is not an ideal method however can be justified; since the measurable amount of remineralization requires sectioning of the tooth in which the orthodontic cases requiring extraction would give the exact amount for remineralization. Thus, well designed randomized controlled trials had added weight of evidence indicating the efficacy of CPP-ACP $(28,31)$. The follow-up time of studies varied from 3 months to 2 years. For the observation of the demineralization / remineralization process the follow-up period; at least 3 months' time is needed $(34,40,41)$ in addition the observation period needed to determine the clinical changes created by CPP-ACP requires a long period of time (31), thus the significant results obtained from this study suggested that long term exposure to CPP-ACP suggests an evidence of greater treatment effects in caries 
Meta Analysis

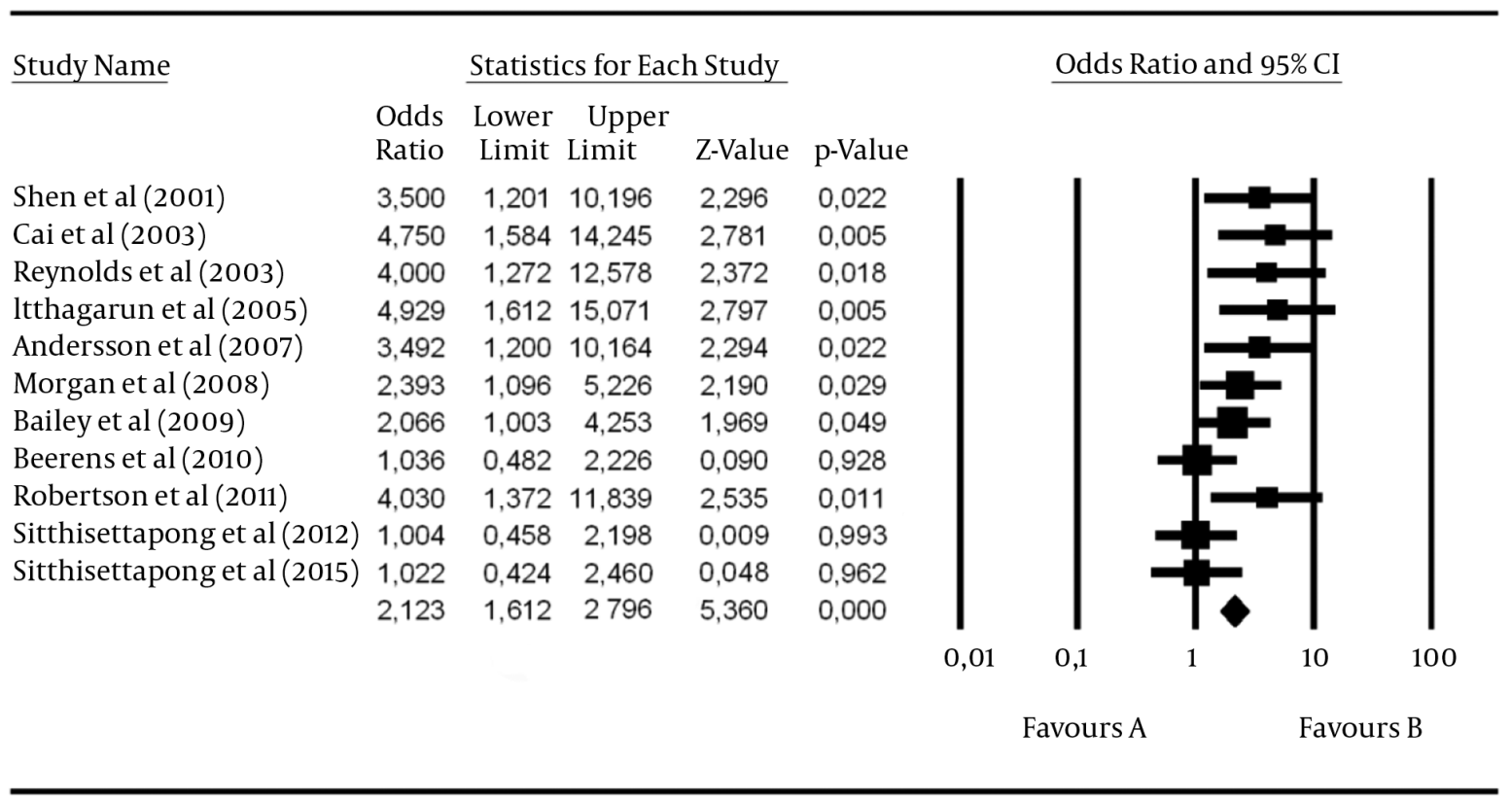

Meta Analysis

Figure 1. Data Were Synthesized With Random Effects Meta-Analysis, With Odds Ratios (OR) and 95\% Confidence Intervals Being Calculated

preventive efficacy. According to another trial, the longterm usage of CPP-ACP reveals a beneficial affect considering remineralizaiton (28). This study is compatible with Reynolds et al. (12) who developed the CPP-ACP application for remineralization providing independent information.

Various methods have been introduced to inspect caries lesions with clinical examination and radiography; and when these methods are used in conjunction with clinical indices like DS/DMFS index the outcomes may be stronger (32). Fluorescence-based devices have recently been introduced for the detection of early caries lesions; such as laser fluorescence (DIAGNOdent) that can detect the lesions at dentine level $(42,43)$; and Quantitative Lightinduced Fluorescence (QLF) which is able to detect the secondary caries, smooth surface caries and demineralization adjacent to orthodontic brackets $(44,45)$.

The potential side effects of CPP-ACP should be taken into consideration. The studies assessing the clinical safety of CPP-ACP showed no significant difference between CPPACP groups and control groups concerning the dental calculus formation, allergies or other side effects $(31-33,36)$.

The meta analysis with systematic reviews are powerful ways for achieving meaningful conclusions of the data collected from the studies; however the weakness caused by heterogeneity and small sample size should be taken into consideration.

To summarize, this meta-analysis has provided the evidence that usage of CPP-ACP increases remineralization and enhances white spot lesions. The effective doses of CPPACP concentrations ranged between $10.0 \mathrm{mg}$ to $56.4 \mathrm{mg}$ in sugar free gum. The results of in situ trials support the effect of CPP-ACP for remineralization and caries prevention.

\subsection{Conclusions}

According to this systematic review, CPP-ACP has a remineralization effect on early caries lesions. In vivo randomized clinical trials provide promising results for the longterm use of CPP-ACP for caries prevention. With the Welldesigned randomized controlled trials on the outcome of caries prevention is guaranteed.

\section{References}

1. Liljemark WF, Bloomquist C. Human oral microbial ecology and dental caries and periodontal diseases. Crit Rev Oral Biol Med. 1996;7(2):180-98. [PubMed: 8875032].

2. Sandberg GE, Sundberg HE, Fjellstrom CA, Wikblad KF. Type 2 diabetes and oral health: a comparison between diabetic and nondiabetic subjects. Diabetes Res Clin Pract. 2000;50(1):27-34. [PubMed: 10936666]. 
3. Aimutis WR. Bioactive properties of milk proteins with particular focus on anticariogenesis. J Nutr. 2004;134(4):989S-95S. [PubMed: 15051859].

4. Shaw JH, Ensfield BJ, Wollman DH. Studies on the relation of dairy products to dental caries in caries-susceptible rats. $J$ Nutr. 1959;67(2):253-73. [PubMed: 13642121].

5. Guggenheim B, Schmid R, Aeschlimann JM, Berrocal R, Neeser JR. Powdered milk micellar casein prevents oral colonization by Streptococcus sobrinus and dental caries in rats: a basis for the cariesprotective effect of dairy products. Caries Res. 1999;33(6):446-54. [PubMed: 10529530].

6. Krobicka A, Bowen WH, Pearson S, Young DA. The effects of cheese snacks on caries in desalivated rats. J Dent Res. 1987;66(6):1116-9. [PubMed: 3476582].

7. Rosen S, Min DB, Harper DS, Harper WJ, Beck EX, Beck FM. Effect of cheese, with and without sucrose, on dental caries and recovery of Streptococcus mutans in rats. J Dent Res. 1984;63(6):894-6. [PubMed: 6588074].

8. Reynolds EC, del Rio A. Effect of casein and whey-protein solutions on caries experience and feeding patterns of the rat. Arch Oral Biol. 1984;29(11):927-33. [PubMed: 6335024].

9. Silva MF, Burgess RC, Sandham HJ, Jenkins GN. Effects of water-soluble components of cheese on experimental caries in humans.J Dent Res. 1987;66(1):38-41. [PubMed: 3476541].

10. Harper DS, Osborn JC, Clayton R, Hefferren JJ. Modification of food cariogenicity in rats by mineral-rich concentrates from milk. J Dent Res. 1987;66(1):42-5. [PubMed: 3497961].

11. Reynolds EC, Cain CJ, Webber FL, Black CL, Riley PF, Johnson IH, et al. Anticariogenicity of calcium phosphate complexes of tryptic casein phosphopeptides in the rat. J Dent Res. 1995;74(6):1272-9. [PubMed: 7629336].

12. Reynolds EC. Anticariogenic complexes of amorphous calcium phosphate stabilized by casein phosphopeptides: a review. Spec Care Dentist. 1998;18(1):8-16. [PubMed: 9791302].

13. Reynolds EC. Remineralization of enamel subsurface lesions by casein phosphopeptide-stabilized calcium phosphate solutions. J Dent Res. 1997;76(9):1587-95. [PubMed: 9294493].

14. Rose RK. Binding characteristics of Streptococcus mutans for calcium and casein phosphopeptide. Caries Res. 2000;34(5):427-31. [PubMed: 11014910].

15. Cai F, Manton DJ, Shen P, Walker GD, Cross KJ, Yuan Y, et al. Effect of addition of citric acid and casein phosphopeptide-amorphous calcium phosphate to a sugar-free chewing gum on enamel remineralization in situ. Caries Res. 2007;41(5):377-83. doi: 10.1159/000104796. [PubMed: 17713338].

16. Iijima Y, Cai F, Shen P, Walker G, Reynolds C, Reynolds EC. Acid resistance of enamel subsurface lesions remineralized by a sugar-free chewing gum containing casein phosphopeptideamorphous calcium phosphate. Caries Res. 2004;38(6):551-6. doi: 10.1159/000080585. [PubMed: 15528910].

17. Roberts AJ. Role of models in assessing new agents for caries prevention-non-fluoride systems. Adv Dent Res. 1995;9(3):304-11. [PubMed: 8615950] discussion 312-4.

18. Neeser JR, Golliard M, Woltz A, Rouvet M, Dillmann ML, Guggenheim B. In vitro modulation of oral bacterial adhesion to saliva-coated hydroxyapatite beads by milk casein derivatives. Oral Microbiol Immunol. 1994;9(4):193-201.

19. Reynolds EC, Riley PF, Storey E. Phosphoprotein inhibition of hydroxyapatite dissolution. CalcifTissue Int. 1982;34 Suppl 2:S52-6. [PubMed: 6293674].

20. Shen P, Cai F, Nowicki A, Vincent J, Reynolds EC. Remineralization of enamel subsurface lesions by sugar-free chewing gum containing casein phosphopeptide-amorphous calcium phosphate. J Dent Res. 2001;80(12):2066-70. [PubMed: 11808763].

21. Hay KD, Thomson WM. A clinical trial of the anticaries efficacy of casein derivatives complexed with calcium phosphate in patients with salivary gland dysfunction. Oral Surg Oral Med Oral Pathol Oral Radiol Endod. 2002;93(3):271-5.

22. Hay KD, Morton RP. The efficacy of casein phosphoprotein-calcium phosphate complex (DC-CP) [Dentacal] as a mouth moistener in patients with severe xerostomia. N Z Dent J. 2003;99(2):46-8. [PubMed: 15332459].

23. Cai F, Shen P, Morgan MV, Reynolds EC. Remineralization of enamel subsurface lesions in situ by sugar-free lozenges containing casein phosphopeptideamorphous calcium phosphate. Aus Dent J. 2003;48(4):240-3.

24. Reynolds EC, Cai F, Shen P, Walker GD. Retention in plaque and remineralization of enamel lesions by various forms of calcium in a mouthrinse or sugar-free chewing gum.J Dent Res. 2003;82(3):206-11. [PubMed: 12598550].

25. Itthagarun A, King NM, Yiu C, Dawes C. The effect of chewing gums containing calcium phosphates on the remineralization of artificial caries-like lesions in situ. Caries Res. 2005;39(3):251-4. doi: 10.1159/000084806. [PubMed:15914989].

26. Kowalczyk A, Botulinski B, Jaworska M, Kierklo A, Pawinska M, Dabrowska E. Evaluation of the product based on Recaldent technology in the treatment of dentin hypersensitivity. Adv Med Sci. 2006;51 Suppl 1:40-2. [PubMed: 17458057].

27. Walker G, Cai F, Shen P, Reynolds C, Ward B, Fone C, et al. Increased remineralization of tooth enamel by milk containing added casein phosphopeptide-amorphous calcium phosphate. J Dairy Res. 2006;73(1):74-8. doi: 10.1017/S0022029905001482. [PubMed: 16433964].

28. Andersson A, Skold-Larsson K, Hallgren A, Petersson LG, Twetman S. Effect of a dental cream containing amorphous cream phosphate complexes on white spot lesion regression assessed by laser fluorescence. Oral Health Prev Dent. 2007;5(3):229-33. [PubMed: 17977295].

29. Reynolds EC, Cai F, Cochrane NJ, Shen P, Walker GD, Morgan MV, et al. Fluoride and casein phosphopeptide-amorphous calcium phosphate. J Dent Res. 2008;87(4):344-8. [PubMed: 18362316].

30. Manton DJ, Walker GD, Cai F, Cochrane NJ, Shen P, Reynolds EC. Remineralization of enamel subsurface lesions in situ by the use of three commercially available sugar-free gums. Int J Paediatr Dent. 2008;18(4):284-90. doi: 10.1111/j.1365-263X.2008.00920.x. [PubMed: 18435723].

31. Morgan MV, Adams GG, Bailey DL, Tsao CE, Fischman SL, Reynolds EC. The anticariogenic effect of sugar-free gum containing CPPACP nanocomplexes on approximal caries determined using digital bitewing radiography. Caries Res. 2008;42(3):171-84. doi: 10.1159/000128561. [PubMed: 18446025].

32. Rao SK, Bhat GS, Aradhya S, Devi A, Bhat M. Study of the efficacy of toothpaste containing casein phosphopeptide in the prevention of dental caries: a randomized controlled trial in 12- to 15-year-old high caries risk children in Bangalore, India. Caries Res. 2009;43(6):430-5. doi: 10.1159/000252976. [PubMed: 19864905].

33. Bailey DL, Adams GG, Tsao CE, Hyslop A, Escobar K, Manton DJ, et al. Regression of post-orthodontic lesions by a remineralizing cream.JDent Res. 2009;88(12):1148-53. doi: 10.1177/0022034509347168. [PubMed: 19887683].

34. Beerens MW, van der Veen MH, van Beek H, ten Cate JM. Effects of casein phosphopeptide amorphous calcium fluoride phosphate paste on white spot lesions and dental plaque after orthodontic treatment: a 3-month follow-up. Eur J Oral Sci. 2010;118(6):610-7. doi:10.1111/j.16000722.2010.00780.x. [PubMed: 21083623].

35. Robertson MA, Kau CH, English JD, Lee RP, Powers J, Nguyen JT. MI Paste Plus to prevent demineralization in orthodontic patients: a prospective randomized controlled trial. Am J Orthod Dentofacial Orthop. 2011;140(5):660-8. doi: 10.1016/j.ajodo.2010.10.025. [PubMed: 22051486].

36. Sitthisettapong T, Phantumvanit P, Huebner C, Derouen T. Effect of CPP-ACP paste on dental caries in primary teeth: a randomized trial. $J$ 
Dent Res. 2012;91(9):847-52. doi: 10.1177/0022034512454296. [PubMed: 22805294].

37. Sitthisettapong T, Doi T, Nishida Y, Kambara M, Phantumvanit P. Effect of CPP-ACP Paste on Enamel Carious Lesion of Primary Upper Anterior Teeth Assessed by Quantitative Light-Induced Fluorescence: A One-Year Clinical Trial. Caries Res. 2015;49(4):434-41. doi: 10.1159/000434728. [PubMed: 26228178].

38. Llena C, Leyda AM, Forner L. CPP-ACP and CPP-ACFP versus fluoride varnish in remineralisation of early caries lesions. A prospective study. EurJ Paediatr Dent. 2015;16(3):181-6. [PubMed: 26418918].

39. Memarpour M, Fakhraei E, Dadaein S, Vossoughi M. Efficacy of fluoride varnish and casein phosphopeptide-amorphous calcium phosphate for remineralization of primary teeth: a randomized clinical trial. Med Princ Pract. 2015;24(3):231-7. doi: 10.1159/000379750. [PubMed: 25895964].

40. Marinho VC, Higgins JP, Sheiham A, Logan S. Fluoride toothpastes for preventing dental caries in children and adolescents. Cochrane Database Syst Rev. 2003(1):CD002278. doi:10.1002/14651858.CD002278.
[PubMed: 12535435].

41. Riley P, Worthington HV, Clarkson JE, Beirne PV. Recall intervals for oral health in primary care patients. Cochrane Data Sys Rev. 2013;12.

42. Bader JD, Shugars DA. A systematic review of the performance of a laser fluorescence device for detecting caries. J Am Dent Assoc. 2004;135(10):1413-26. [PubMed: 15551982].

43. Pretty IA, Ellwood RP. The caries continuum: opportunities to detect, treat and monitor the re-mineralization of early caries lesions. J Dent. 2013;41 Suppl 2:S12-21. doi: 10.1016/j.jdent.2010.04.003. [PubMed: 23985434].

44. Angmar-Mansson B, ten Bosch JJ. Quantitative light-induced fluorescence (QLF): a method for assessment of incipient caries lesions. Dentomaxillofac Radiol. 2001;30(6):298-307. doi: 10.1038/sj/dmfr/4600644. [PubMed: 11641727].

45. Pretty IA. Caries detection and diagnosis: novel technologies. J Dent. 2006;34(10):727-39. doi: 10.1016/j.jdent.2006.06.001. [PubMed: 16901606]. 
Table 1. Evidence OF Clinical Efficiency AND Efficacy of CPP-ACP

\begin{tabular}{|c|c|c|c|c|c|c|}
\hline Author,Year & Population & Intervention & Controls & Outcome & Conclusion & Study Design \\
\hline Shen et al, 2001 & $\begin{array}{l}30 \text { adults (age: } 23 \text { - } \\
40 \text { years) }\end{array}$ & $\begin{array}{l}\text { In situ, gum with } \\
0.19,10,18.8,56,4 \\
\text { mg CPP-ACP }\end{array}$ & $\begin{array}{l}\text { Crossover washout } 1 \\
\text { week }\end{array}$ & $\begin{array}{l}\% \text { subsurface } \\
\text { remineralization }\end{array}$ & $\begin{array}{l}\text { Dose-based } \\
\text { increased in } \\
\text { remineralization } \\
\text { with CPP-ACP }\end{array}$ & RCT (Double-blind) \\
\hline $\begin{array}{l}\text { Hay and Thomson, } \\
2002\end{array}$ & $\begin{array}{l}124 \text { subjects (age: } 53 \\
\pm 14 \text { years) }\end{array}$ & $\begin{array}{l}63 \text { subjects, topical } \\
\text { CD-CP mouthrinse. } \\
3 \text { times/day }\end{array}$ & $\begin{array}{l}61 \text { subjects, } \\
0,05 \% \mathrm{NaF} \\
\text { mouthrinse. } 3 \\
\text { times/day }\end{array}$ & $\begin{array}{l}\text { Coronal caries } \\
\text { prevention, bite } \\
\text { wing radiographic } \\
\text { screening, } 12 \\
\text { months }\end{array}$ & $\begin{array}{l}\text { CD-CP application } \\
\text { successful for caries } \\
\text { prevention in dry } \\
\text { mouth }\end{array}$ & $\begin{array}{l}\text { RCT (Double-blind } \\
\text { unclear) }\end{array}$ \\
\hline $\begin{array}{l}\text { Hay and Morton, } \\
2003\end{array}$ & $\begin{array}{l}38 \text { adults (age: older } \\
\text { than } 25 \text { years) }\end{array}$ & $\begin{array}{l}\text { CD-CP application } \\
\text { for } 2 \text { weeks }\end{array}$ & $\begin{array}{l}\text { Mouth moistening } \\
\text { with spring water, } \\
\text { chewing gum, } \\
\text { artificial saliva }\end{array}$ & Questionnaire & $\begin{array}{l}\text { CD-CP } \\
\text { advantageous in } \\
\text { oral moistening } \\
\text { and caries } \\
\text { prevention in } \\
\text { xerostomia }\end{array}$ & Questionnaire \\
\hline $\begin{array}{l}\text { Reynolds et al, } \\
2003\end{array}$ & $\begin{array}{l}30 \text { adults (age: } 22 \text { - } \\
44 \text { years) }\end{array}$ & $\begin{array}{l}2 \text { parts: 1-Mouth } \\
\text { rinse: a-2\%CPP-ACP, } \\
\text { b-6\% CPP-ACP, } \\
\text { c-Ca }{ }^{+} \mathrm{PO}_{4} \text { mouth } \\
\text { rinse, d-Deionized } \\
\text { water, } 2 \text {-Gum (pellet } \\
\text { or } \mathrm{Swab} \text { ) with, } \\
\mathrm{a}-\mathrm{CaCO}_{3} \text { or } \\
\mathrm{CaHPO}_{4} / \mathrm{CaCO}_{3} \text { or } \\
\mathrm{CPP}-\mathrm{ACP}, \text { b-gum } \\
\text { pellets with } 9,5 \mathrm{mg} \\
\mathrm{CPP}-\mathrm{ACP}\end{array}$ & $\begin{array}{l}\text { Crossover: } \\
\text { mouthrinse } \\
\text { washout: } 4 \text { weeks }\end{array}$ & $\begin{array}{l}\text { Mouthrinse: plaque } \\
\mathrm{Ca} \text { and inorganic } \\
\mathrm{PO}_{4} \text { levels; Gum: } \\
\text { \%subsurface } \\
\text { remineralization }\end{array}$ & $\begin{array}{l}\text { CPP leading ACP to } \\
\text { tooth surface and } \\
\text { stabilization }\end{array}$ & $\begin{array}{l}\text { RCT (Double-blind, } \\
\text { crossover, chewing } \\
\text { gum in situ) }\end{array}$ \\
\hline $\begin{array}{l}\text { Itthagarun et al, } \\
2005\end{array}$ & $\begin{array}{l}12 \text { adults (age: } 20 \text { - } \\
47 \text { years) }\end{array}$ & $\begin{array}{l}3 \text { gums: 1-with } 30 \\
\text { mg urea, } 2 \text {-30 mg } \\
\text { urea +25mg } \\
\text { dicalcium } \\
\text { phosphate } \\
\text { dehydratre; } 3 \text { - } \\
\text { 30mg urea + } 47 \mathrm{mg} \\
\text { CPP-ACP }\end{array}$ & $\begin{array}{l}\text { Crossover design } \\
\text { with 21-day test } \\
\text { period for each type } \\
\text { of gum followed by } \\
5 \text { day washouts } \\
\text { after test }\end{array}$ & $\begin{array}{l}2 \text { outcomes: } 1 \text { - mean } \\
\text { percentage change } \\
\text { in lesion depth; } \\
\text { 2-mean percentage } \\
\text { change in mineral } \\
\text { content }\end{array}$ & $\begin{array}{l}\text { Potential of caries } \\
\text { prevention with } \\
\text { gum containing } \\
\text { urea, dicalcium } \\
\text { phosphate or } \\
\text { CPP-ACP }\end{array}$ & $\begin{array}{l}\text { RCT } \\
\text { (Double-blinded, } \\
\text { crossover, in situ) }\end{array}$ \\
\hline $\begin{array}{l}\text { Kowalczyk et al, } \\
2006\end{array}$ & $\begin{array}{l}13 \text { adults (age: } 23 \text { - } \\
48 \text { years) }\end{array}$ & $\begin{array}{l}\text { GC tooth mousse } \\
\text { applied to } 101 \text { teeth } \\
\text { for } 3 \text { minutes }\end{array}$ & None & $\begin{array}{l}\text { Pain intensity } \\
\text { following GC tooth } \\
\text { mousse application }\end{array}$ & $\begin{array}{l}\text { Short term } \\
\text { therapeutic effect } \\
\text { in pain removal }\end{array}$ & $\begin{array}{l}\text { Uncontrolled } \\
\text { cohort study,. No } \\
\text { blinding, no } \\
\text { control. }\end{array}$ \\
\hline Walker et al, 2006 & 10 adults & $\begin{array}{l}\text { In situ: } 200 \mathrm{~mL} \text { test } \\
\text { milk or control } \\
\text { milk with } 2 \text { or } 5 \mathrm{~g} \\
\text { CPP-ACP/L }\end{array}$ & $\begin{array}{l}\text { Control: crossover, } \\
\text { washout } 1 \text { week }\end{array}$ & $\begin{array}{l}\% \text { subsurface } \\
\text { remineralization }\end{array}$ & $\begin{array}{l}\text { Remineralizing } \\
\text { activity with milk } \\
\text { containing CPP-ACP }\end{array}$ & $\begin{array}{l}\text { RCT } \\
\text { (Double-blinded, } \\
\text { crossover, short } \\
\text { washout, small } \\
\text { sample size) }\end{array}$ \\
\hline $\begin{array}{l}\text { Andersson et al, } \\
2007\end{array}$ & $\begin{array}{l}26 \text { adolescents- } 60 \\
\text { teeth (age: } 14,6 \\
\text { years) }\end{array}$ & $\begin{array}{l}60 \text { teeth, } 70 \text { WSL's. } \\
\text { CPP-ACP application } \\
3 \text { months-12 months } \\
\text { follow-up }\end{array}$ & $\begin{array}{l}13 \text { controls } 62 \text { WSL's. } \\
\text { Daily topical } \\
\text { CPP-ACP cream }\end{array}$ & $\begin{array}{l}\text { Blind essessment } \\
\text { for } 1,3,6,12 \text { months }\end{array}$ & $\begin{array}{l}\text { Both CPP-ACP and } \\
\text { NaF reversed WSL's }\end{array}$ & $\begin{array}{l}\text { RCT } \\
\text { (Single-blinded) } \\
\text { Small sample, no } \\
\text { power analysis, no } \\
\text { significant } \\
\text { difference with } \\
\text { laser fluorescence }\end{array}$ \\
\hline
\end{tabular}




\begin{tabular}{|c|c|c|c|c|c|c|}
\hline Cai et al, 2007 & $\begin{array}{l}10 \text { subjects (age: } 23 \text { - } \\
46 \text { years) }\end{array}$ & $\begin{array}{l}\text { Sugar-free pellet } \\
\text { gum with } 20 \mathrm{mg} \\
\text { cirtic acid }+18,8 \mathrm{mg} \\
\text { CPP-ACP; gum with } \\
\text { citric acid; gum } \\
\text { with no citric acid } \\
\text { and no CPP-ACP }\end{array}$ & $\begin{array}{l}\text { Crossover washout } \\
\text { for } 2 \text { weeks } \\
\text { followed by one } \\
\text { week washout }\end{array}$ & $\begin{array}{l}\text { Percentage of } \\
\text { subsurface } \\
\text { remineralization }\end{array}$ & $\begin{array}{l}\text { CPP-ACP } \\
\text { significantly } \\
\text { effective on enamel } \\
\text { mineralization }\end{array}$ & $\begin{array}{l}\text { RCT (Double - } \\
\text { blinded, crossover, } \\
\text { in situ) }\end{array}$ \\
\hline $\begin{array}{l}\text { Reynolds et al, } \\
2008\end{array}$ & $\begin{array}{l}14 \text { subjects (age: } 21 \text { - } \\
45 \text { years) }\end{array}$ & $\begin{array}{l}2 \text { Trials: } 1 \text { - } 3 \\
\text { mouthrinses } \\
\text { containing; a-2\% } \\
\text { CPP-ACP + } 450 \text { ppm } \\
\text { F, b-450 ppm F, } \\
\text { c-placebo, } \\
\text { 2-Toothpaste } \\
\text { containing:, } \\
\text { a-Placebo, b-1100 } \\
\text { ppm F, c-2800 ppm } \\
\text { F, d-2\% CPP-ACP, e-2\% } \\
\text { CPP-ACP + } 1100 \text { ppm } \\
\text { F }\end{array}$ & $\begin{array}{l}\text { Mouthrinse:Crossover } \\
\text { washout } 4 \text { days } 3 \\
\text { times daily for } 15 \\
\text { days; Toothpaste, } \\
\text { Crossover trial with } \\
4 \text { rinses/day for } 14 \\
\text { days followed by } 7 \\
\text { days washout }\end{array}$ & $\begin{array}{l}\text { Approximal caries } \\
\text { screened by } \\
\text { bitewing } \\
\text { radiographs. \% } \\
\text { subsurface } \\
\text { remineralization } \\
\text { and plaque calcium } \\
\text { and inorganic } \\
\text { phosphate levels }\end{array}$ & $\begin{array}{l}\text { CPP is important for } \\
\text { the stabilization of } \\
\text { ACP on tooth } \\
\text { surface }\end{array}$ & $\begin{array}{l}\text { RCT (Double } \\
\text { blinded, crossover, } \\
\text { in situ) }\end{array}$ \\
\hline Manton et al, 2008 & 10 subjects & $\begin{array}{l}3 \text { types of gum: } \\
\text { 1-sorbitol/xylitol } \\
\text { slab gum with no } \\
\text { CPP-ACP; } \\
\text { 2-sorbitol/xylitol } \\
\text { pellet gum with no } \\
\text { CPP-ACP; 3-two gum } \\
\text { pellets with 10mg } \\
\text { CPP-ACP }\end{array}$ & $\begin{array}{l}\text { Crossover design } 2 \\
\text { weeks test period, } \\
\text { usage: } 4 \text { times/day } \\
\text { followed by 7-day } \\
\text { washout period }\end{array}$ & $\begin{array}{l}\% \text { subsurface } \\
\text { interventions }\end{array}$ & $\begin{array}{l}\text { Gum containing } \\
\text { CPP-ACP provided a } \\
\text { superior } \\
\text { remineralization } \\
\text { activity }\end{array}$ & $\begin{array}{l}\text { RCT (Double-blind, } \\
\text { crossover, in situ) }\end{array}$ \\
\hline Morgan et al, 2008 & 2720 children & $\begin{array}{l}926 \text { children } \\
\text { completed trial. } \\
\text { Gum with } 54 \mathrm{mg} \\
\text { CPP-ACP. } 3 \text { times/day }\end{array}$ & $\begin{array}{l}894 \text { children } \\
\text { completed trial. } \\
\text { Sorbitol-based gum. } \\
3 \text { times/day }\end{array}$ & $\begin{array}{l}\text { Approximal caries } \\
\text { screened by } \\
\text { bitewing } \\
\text { radiographs }\end{array}$ & $\begin{array}{l}54 \text { mg CPP-ACP gum } \\
\text { significantly slowed } \\
\text { progression and } \\
\text { enhanced } \\
\text { regression of } \\
\text { approximal caries }\end{array}$ & RCT (Double-blind) \\
\hline Rao et al, 2009 & $\begin{array}{l}150 \text { children (age: } 12 \\
-15 \text { years) }\end{array}$ & $\begin{array}{l}\text { 3 groups: } \\
\text { 1-Toothpaste with } \\
\text { 2\% w/w CPP; } \\
\text { 2-Toothpaste with } \\
\text { 0.76\% SMFP; } \\
\text { 3-Placebo } \\
\text { toothpaste without } \\
\text { CPP or SMFP }\end{array}$ & $\begin{array}{l}\text { Toothpaste applied } \\
24 \text { months }\end{array}$ & $\begin{array}{l}\text { Oral Hygiene Index } \\
\text { Scoring }\end{array}$ & $\begin{array}{l}2 \% \text { CPP toothpaste } \\
\text { had similar effects } \\
\text { as } 0.76 \% \text { SMFP. Both } \\
\text { greater } \\
\text { reminerlization } \\
\text { effect than placebo } \\
\text { toothpaste }\end{array}$ & $\begin{array}{l}\text { RCT (Double-blind, } \\
\text { subjective } \\
\text { assessment) }\end{array}$ \\
\hline Bailey et al, 2009 & $\begin{array}{l}45 \text { subjects (age: } 12 \text { - } \\
18 \text { years) }\end{array}$ & $\begin{array}{l}23 \text { subjects were } \\
\text { applied } \\
\text { remineralizing } \\
\text { cream containing } \\
\text { CPP-ACP }\end{array}$ & $\begin{array}{l}22 \text { control subject } \\
\text { were applied } \\
\text { placebo }\end{array}$ & $\begin{array}{l}\text { Assessment was } \\
\text { done with ICDAS } \\
\text { criteria }\end{array}$ & $\begin{array}{l}\text { CPP-ACP cream } \\
\text { group showed a } \\
\text { significant } \\
\text { regression of WSL's } \\
\text { over } 12 \text { weeks. }\end{array}$ & $\begin{array}{l}\text { RCT (Double-blind, } \\
\text { subjective } \\
\text { assessment) }\end{array}$ \\
\hline Beerens et al, 2010 & $\begin{array}{l}54 \text { subjects (age: } \\
15,5 \pm 1,6 \text { years) }\end{array}$ & $\begin{array}{l}511 \text { caries effected } \\
\text { surfaces were } \\
\text { applied Paste with } \\
\text { CPP-ACP or control } \\
\text { paste }\end{array}$ & $\begin{array}{l}491 \text { Control group } \\
\text { surface was } \\
\text { monitored and was } \\
\text { applied control } \\
\text { paste }\end{array}$ & $\begin{array}{l}\text { Assessment with } \\
\text { QLF images } \\
\text { captured just after } \\
\text { debonding, after } 6 \\
\text { weeks and after } 12 \\
\text { weeks }\end{array}$ & $\begin{array}{l}\text { No differences } \\
\text { between groups }\end{array}$ & RCT (Double-blind) \\
\hline $\begin{array}{l}\text { Robertson et al, } \\
2011\end{array}$ & $\begin{array}{l}50 \text { subjects (age: } \\
\text { older than } 12 \text { years) }\end{array}$ & $\begin{array}{l}26 \text { patients were } \\
\text { applied MI paste } \\
\text { Plus }\end{array}$ & $\begin{array}{l}24 \text { patiens were } \\
\text { applied placebo } \\
\text { paste }\end{array}$ & $\begin{array}{l}\text { Enamel } \\
\text { decalcification } \\
\text { index was used }\end{array}$ & $\begin{array}{l}\text { MI paste reduced } \\
\text { the WSL's }\end{array}$ & $\begin{array}{l}\text { RCT (Double-blind, } \\
\text { subjective } \\
\text { assessment) }\end{array}$ \\
\hline $\begin{array}{l}\text { Sitthisettapong et } \\
\text { al, } 2012\end{array}$ & $\begin{array}{l}229 \text { children }(3,5- \\
4,5 \text { years })\end{array}$ & $\begin{array}{l}150 \text { children was } \\
\text { applied CPP-ACP } \\
\text { paste }\end{array}$ & $\begin{array}{l}146 \text { control children } \\
\text { was applied } \\
\text { placebo paste }\end{array}$ & $\begin{array}{l}\text { Assessment was } \\
\text { performed with } \\
\text { ICDAS criteria }\end{array}$ & $\begin{array}{l}\text { No difference } \\
\text { between groups }\end{array}$ & $\begin{array}{l}\text { RCT (Double-blind } \\
\text { subjective } \\
\text { assessment) }\end{array}$ \\
\hline $\begin{array}{l}\text { Sitthisettapong et } \\
\text { al, } 2015\end{array}$ & $\begin{array}{l}103 \text { children (age: } \\
2,5-3,5 \text { years) }\end{array}$ & $\begin{array}{l}53 \text { children was } \\
\text { applied } 10 \% \text { w/v } \\
\text { CPP-ACP with } \\
\text { fluoridated } \\
\text { toothpaste }\end{array}$ & $\begin{array}{l}50 \text { children placebo } \\
\text { control }\end{array}$ & $\begin{array}{l}6 \text { months and } 1 \text { year } \\
\text { follow up with QLF }\end{array}$ & $\begin{array}{l}\text { No difference } \\
\text { between groups at } \\
\text { any time points }\end{array}$ & CCT \\
\hline Llena et al, 2015 & $\begin{array}{l}786 \text { White spot } \\
\text { lesions (age: } 6 \text { - } 14 \\
\text { years) }\end{array}$ & $\begin{array}{l}3 \text { groups: 1-GC Tooth } \\
\text { Mousse; } 2 \text {-MI Paste } \\
\text { Plus; 3-Duraphat } \\
\text { Fluoride Varnish }\end{array}$ & $\begin{array}{l}\text { Assessment at } 4,8 \text {, } \\
12 \text { weeks }\end{array}$ & $\begin{array}{l}\text { IDAS and QLF at } 4,8 \\
\text { and } 12 \text { weeks }\end{array}$ & $\begin{array}{l}\text { CPP-ACP effective on } \\
\text { smooth surface } \\
\text { caries not in pits } \\
\text { and fissures }\end{array}$ & RCT (Double-blind) \\
\hline
\end{tabular}




\begin{tabular}{|c|c|c|c|c|c|c|}
\hline $\begin{array}{l}\text { Memarpour et al, } \\
2015\end{array}$ & $\begin{array}{l}140 \text { children (age: } 1 \text { - } \\
3 \text { years) }\end{array}$ & $\begin{array}{l}4 \text { groups: 1-Control, } \\
\text { 2-Oral hygiene, } \\
\text { dietary counseling, } \\
\text { 3-Fluoride varnish } \\
\text { at } 4,8,12 \text { months, } \\
\text { 4-Tooth mousse, } 12 \\
\text { months }\end{array}$ & $\begin{array}{l}35 \text { children, Control } \\
\text { group: no } \\
\text { intervention }\end{array}$ & $\begin{array}{l}\text { At } 4,8 \text { and } 12 \\
\text { months, DMFT } \\
\text { index was used }\end{array}$ & $\begin{array}{l}\text { Fluoride varnish } \\
\text { and CPP-ACP } \\
\text { reduced WSL size }\end{array}$ & RCT \\
\hline
\end{tabular}

